\title{
Wyjaśnianie empiryczne a wyjaśnianie interpretacyjne działań politycznych
}

\section{Empirical Explanation and Interpretive Explanation of Political}

\section{Activities}

\begin{abstract}
The article arranges issues related to explaining social phenomena, primarily political activities. Three types of explanation are mentioned in the literature: a reason explanation, an interpretative explanation (humanistic, understanding) and an integral explanation combining these two. The author discusses the types of explanation, where he replaces the term "causal explanation" with the term "empirical explanation". Then he characterizes political activities and their results as an object of explanation. In the last part, on two examples, he examines the practice of empirical and interpretive explanation. With reference to the example of interpretive explanation, he recalls abductive reasoning, i.e. inference to the best explanation. In the interpretation process, in the absence of irrefutable evidence, none of the hypotheses can be confirmed. They can only be enhanced or made more attractive. Considering the imperfections of empirical and interpretive explanation, one should strive to use them complementarily.
\end{abstract}

Keywords: empirical explanation, interpretive explanation, integral explanation, political actions, naturalism, anti-naturalism, abductive reasoning

\section{Wprowadzenie}

- Czy rozumiesz, co się dzieje?

- Wyjaśnić Ci?

- Nie. Wyjaśnić mogę sobie sam. Ale czy to rozumiesz? 
Taki dialog pojawił się w poście zamieszczonym przez kogoś na Facebooku. Napisał go ktoś (bądź przepisał od kogoś), kto być może wie, że pozytywiści kładą nacisk na wyjaśnianie zachowań ludzkich, podczas gdy interpretacjoniści na ich rozumienie (Marsh, Furlong, 2006, s. 19-20). Jest to moja niepozytywistyczna interpretacja zachowania autora wpisu, ponieważ nie mam dowodu, że on to wie. Jest to jednocześnie hipoteza, którą można uprawdopodobniać. Taką interpretację nazywa się wyjaśnieniem interpretacjonistycznym, hermeneutycznym, humanistycznym, rozumiejącym, a przynajmniej spekulacją: na pomysł przytoczonej rozmowy (bądź jej przytoczenia) wpadła raczej osoba, która zna podstawowe rozbieżności dzielące świat nauki w sprawie metod badania społeczeństwa. Nie da się jednocześnie wykluczyć, że ich nie zna.

Odwołując się do elementarnej wiedzy podręcznikowej, można by przytoczony dialog rozwinąć, wkładając $\mathrm{w}$ usta drugiego rozmówcy kolejne pytanie: „A jak chciałbyś to rozumieć?”. Czy intuicyjnie, empatycznie w myśl sugestii Wilhelma Diltheya i jego zwolenników, czy fenomenologicznie, jak widział to Edmund Husserl i jego zwolennicy, czy przez rekonstrukcję tzw. sytuacji hermeneutycznej, jak wyobrażał to sobie Martin Heidegger i inni hermeneuci, czy indywidualizująco, przez rekonstrukcję motywów działania, co postulowali Heinrich Rickert i Max Weber, czy przez porównywanie (wyjaśnianie strukturalne), czy przez opis (Topolski, 1978, s. 23)? Propozycje rodzajów rozumienia, sposobów posługiwania się pojęciem rozumienia można oczywiście mnożyć poprzez przywoływanie koncepcji postmodernistycznych i postrukturalistycznych Jacques'a Derridy, Michela Foucaulta i innych oraz koncepcji opisu gęstego sformułowanej przez Clifforda Geertza, postulującej w celu wyjaśniania zachowań ludzkich badanie przede wszystkim ich kontekstu (Bevir, Rhodes, 2006, s. 135139). Ponadto, interpretując jakieś zjawisko, chcąc zrozumieć, dlaczego coś się działo lub dzieje, powinno się sprawdzić, czy tego rodzaju przypadku nie dotyczy uogólnienie teoretyczne. $Z$ reguły niemożliwa jest przy tym ucieczka przed jakimś systemem aksjologicznym zabarwiającym rozumienie. Dodatkowe komplikacje $\mathrm{w}$ interpretowaniu zjawisk społecznych spowodowane są odmiennymi zapatrywaniami na kolejność postępowania badawczego. Jedni uważają, że aby zrozumieć, należy wyjaśnić, a drudzy - że aby wyjaśnić, trzeba zrozumieć (Topolski, 1978, s. 22).

Powyższe obrazuje złożoność zagadnienia wyjaśniania oraz interpretowania zjawisk społecznych, skalę trudności, wobec których staje ich badacz. Nie jest celowe, a wręcz jest niemożliwe odniesienie się w tym artykule do zawiłości dyskursu na ten temat, obecnego w literaturze co najmniej od połowy XIX wieku i sięgającego korzeniami starożytności. Niemniej, aby poruszyć temat zawarty $\mathrm{w}$ tytule niniejszego tekstu oraz hołdując maksymie Repetitio est mater studiorum, należy tutaj niektóre oczywistości przytoczyć. 


\section{Rodzaje wyjaśnień zjawisk społecznych (politycznych)}

$\mathrm{Na}$ wstępie trzeba podkreślić (nie wdając się w szczegóły tłumaczenia łacińskiego słowa interpretatio oraz greckiego hermeneuo na inne języki), że każda interpretacja jest wyjaśnieniem, lecz nie każde wyjaśnienie interpretacją. Należy od razu dodać, że każdy zabieg hermeneutyczny jest równoznaczny z interpretacją, lecz nie każda interpretacja $z$ zabiegiem hermeneutycznym. Interpretacją nie jest między innymi tzw. wyjaśnienie naukowe - nazywane myląco przyczynowym - cechujące nauki przyrodnicze oraz pozytywizm w naukach społecznych. Myląco dlatego, że przyczyny działań społecznych są nie tylko wyjaśniane: one są też interpretowane. Biorąc to pod uwagę, przyjmuję za właściwszy termin „wyjaśnienie empiryczne”, który jest przeciwstawny terminowi „wyjaśnienie interpretacyjne”. Jest ono rezultatem poczynionych badań empirycznych, nie zaś procesu interpretacyjnego. W literaturze wymienia się trzy rodzaje wyjaśnień cechujących nauki społeczne: wyjaśnienie przyczynowe, które zastępuję właśnie pojęciem wyjaśnienia empirycznego, wyjaśnienie interpretacyjne (rozumiejące, humanistyczne), czyli po prostu interpretację, oraz wyjaśnienie integralne, łączące te dwa. Wyjaśnienie empiryczne bywa też nazywane krótko wyjaśnieniem, a wyjaśnienie interpretacyjne - rozumieniem. Istnieją również poglądy podważające taki schemat. Jerzy Topolski traktuje rozumienie jako efekt wyjaśniania, efekt składników badań, które jego zdaniem tworzą interpretację (o czym niżej), a Tadeusz Klementewicz interpretację humanistyczną, wyjaśnienie przyczynowe oraz integralne obejmuje klamrą „rozumienie” (Klementewicz, 2010, s. 107).

$\mathrm{U}$ podstaw przedstawionych rozróżnień leży arystotelesowska koncepcja czterech przyczyn powodujących istnienie rzeczy, ich ruch i zajście skutku: 1) aby rzecz zaistniała, musi z czegoś powstać (przyczyna materialna); 2) aby rzecz miała dany kształt, musi być uformowana (przyczyna formalna); 3) aby rzecz ulegała zmianie, coś musi wprawiać ją w ruch (przyczyna sprawcza); 4) aby rzecz była w ruchu, konieczny jest jego cel, kierunek (przyczyna celowa). Ten model interpretacji był wypierany z nauki w erze nowożytnej w związku z kształtowaniem się nowych założeń. Nauka zrezygnowała z czynienia zjawisk zrozumiałymi przez wskazanie celu, któremu służą, na rzecz wyjaśniania i przewidywania zjawisk w kategoriach przyczynowo-mechanistycznych. Z arystotelesowskiego modelu - jako przyczynę wyjaśniającą rzeczywistość - pozostawiono tylko przyczynę sprawczą (Krasnodębski, 1986, s. 13-17).

Od Kartezjusza i Francisa Bacona zaczęto też przyjmować, że przyczyna sprawcza nie może być domyślna, że to, co wyjaśnia rzeczywistość, powinno być uzyskiwane zmysłowo i poprzez doświadczenie. Domyślność przyczyny (hipoteza) mogła być tylko czasowa i powinna zniknąć wskutek wyjaśnienia empirycznego. Wojciech Sady pisze, że „Bacon zezwalał (...) w pewnych sytuacjach na stawianie hipotez, ale zaraz potem nakazywał je eliminować za pomocą eksperymentów rozstrzygających, tak aby w nauce zostawały jedynie prawdy dowiedzio- 
ne" (Sady, 1996, s. 80). W wypadku wyjaśnienia interpretacyjnego jest inaczej, gdyż tym, co wyjaśnia dany skutek, jest właśnie hipoteza, nie zaś potwierdzony zmysłowo (prawdziwie lub błędnie) fakt. Jeżeli w sprawie interpretowanego działania wychodzi na jaw coś, co wskazuje jego przyczynę, to interpretacja przekształca się w wyjaśnienie empiryczne. Kiedy ktoś się spóźnia na umówione spotkanie, wtedy można to różnie interpretować, rozważając przypuszczenia (hipotezy) dotyczące przyczyny spóźnienia. Kiedy dowiadujemy się, że spóźnienie było spowodowane na przykład awarią windy, w której została uwięziona oczekiwana osoba, wtedy sprawa się wyjaśnia i na interpretacje nie ma już miejsca. Mogą się ewentualnie pojawić domysły na temat przyczyn awarii windy, ale to już jest kolejna opowieść.

W okresie nowożytnym przyjęto również, iż zebrane za pośrednictwem zmysłów dane powinny w drodze indukcji stanowić podstawę budowania teorii empirycznej nadającej się do jej potwierdzania w drodze testowania na kolejnych danych. Kwestionowano celowość tworzenia teorii a priori oraz teorii normatywnych jako niestanowiących uogólnień pozwalających na wyjaśnienie pojedynczych przypadków.

$\mathrm{Na}$ to nałożyła się kartezjańska koncepcja rozdzielenia świata na dwie substancje: przyrodę z jednej strony, a myślącego człowieka, człowieka jako istoty duchowej i konsekwentnie wszystkich zjawisk kultury, życia społecznego - z drugiej. Jednocześnie Kartezjusz stwierdził, że myślący człowiek, będąc podmiotem poznającym przyrodę $\mathrm{z}$ zewnątrz, nie jest całkowicie odrębny od przedmiotu swojego poznania. Jego samego bowiem tworzy zarówno rzeczywistość umysłowa, jak i rzeczywistość fizyczna. Ten dystans do skrajnego dualizmu sprzyjał idei przenoszenia zasad wyjaśniania empirycznego, przyjętego do badania przyrody, na badanie człowieka (jego psychiki) oraz społeczeństwa.

Ostatecznie w pierwszej połowie XIX wieku Auguste Comte, inicjator pozytywizmu, sformułował explicite postulat zrównania nauk społecznych $\mathrm{z}$ naukami przyrodniczymi w zakresie stosowania procedur badawczych. Przyjęto, że przedmiot nauk społecznych i przyrodniczych jest zasadniczo taki sam, gdyż przyroda i społeczeństwo mają taką samą naturę, i odwołując się do założeń eksploracyjnych nauk przyrodniczych określono dyrektywy, którymi powinni kierować się badacze społeczeństwa. Oto niektóre z nich (bez dyrektyw dotyczących przewidywania i wyprowadzania wskazań). Po pierwsze, poznanie naukowe winno być ograniczone do faktów bezpośrednio obserwowalnych zmysłowo. Po drugie, wszelkie uogólnienia powinny być tworzone drogą ostrożnej indukcji, poprzez gromadzenie coraz liczniejszych obserwacji faktów, które następnie należy klasyfikować według podobieństw. Po trzecie, prawa naukowe należy sprowadzać do prostych tez o zależnościach między obserwowalnymi faktami: albo tego typu, że pewne fakty występują razem, albo że następują po sobie (Sztompka, 2002, s. 23). 
Tym samym w pozytywizmie przyjęto metodę wyjaśniania empirycznego zjawisk społecznych przez bezpośrednie obserwowanie zmysłowe. Coś wyjaśnić, to znaczy zobaczyć, jak jest, lub przedstawić dowody, jak było. Wobec stanowiska pozytywistycznego w naukach o społeczeństwie pojawiała się krytyka. Pewność poznania zmysłowego podważał już Immanuel Kant, postulując równocześnie przyjmowanie bez dowodu założeń teoretycznych wywodzonych z innych przesłanek, ukierunkowujących badania. Kwestionując paradygmat pozytywistyczny, wskazywano, „że w świecie ludzkim występują rzeczy niespotykane w przyrodzie, a mianowicie znaczenia, sensy, symbole, reguły, normy, wartości, słowem kultura”, twierdzono, że "społeczeństwo jest fundamentalnie odmienne od przyrody" (tamże). Podkreślano, że zjawiska społeczne cechuje niepowtarzalność, że trudno je mierzyć i uogólniać. Świat społeczny - pisze Małgorzata Kołodziejczak - „tworzą refleksyjne podmioty, uwikłane w strukturę rozmaitych interakcji”, a to wymaga "takiej perspektywy, która pozwoli poznać, zrozumieć rzeczywistość społeczną w całej jej złożoności - historycyzmie, intencjonalności, autodeterminacji, niepowtarzalności” (Kołodziejczak, 2009, s. 8). Tego rodzaju konstatacje prowadziły do przekonania, że wyjaśnianie zjawisk społecznych polega nie tyle na wskazywaniu „prawidłowości wynikających ze związków przyczynowo-skutkowych, ile na odczytaniu (rozumieniu) subiektywnego sensu działań ludzkich, podejmowanych każdorazowo w wyjątkowym, specyficznym kontekście społecznym (i jednocześnie ten kontekst współtworzący) poprzez swoją aktywność" (tamże; zob. także: Giddens, 2001, s. 139 i n.).

W 1858 roku historyk niemiecki Johann Droysen w książce Zarys historyki wymienił trzy możliwe metody naukowe: spekulatywną (filozoficzną lub teologiczną), matematyczno-fizykalną i historyczną. Przyjął - pisze Zdzisław Krasnodębski, cytując fragment książki filozofa Karla-Ottona Apla (Die Erklären, Verstehen-Kontroverse in transzendentalpragmatischer Sicht z 1979 roku) - że ich „istota polega na: poznawaniu, wyjaśnianiu, rozumieniu” (Krasnodębski, 1986, s. 26). Dodaje, że w ten sposób „po raz pierwszy uczynione zostało rozróżnienie między wyjaśnianiem i rozumieniem jako dwiema metodami naukowymi i użyte do uzasadnienia odmienności nauk historycznych od nauk przyrodniczych. Tak, historycznie biorąc, rozpoczął się «spór o rozumienie»" (tamże).

Dało to początek uprawianiu nauk społecznych z perspektywy antypozytywistycznej, nazywanej też humanistyczną, antynaturalistyczną oraz hermeneutyczną, i oznaczało częściowy powrót do koncepcji Arystotelesa: w procesie rozumienia działania badacze powinni kierować się „nie na to, co je spowodowało, lecz na to, co je uzasadniało w oczach aktora", czyli podmiotu działania (Bachryj-Krzywaźnia, 2016, s. 138). „Przyczynowość jest tu więc rozumiana w sposób teleologiczny, nie zaś sprawczy" (tamże). Czy znaczy to, że wyraziciele stanowiska antypozytywistycznego nie dociekają przyczyn sprawczych działań i koncentrują się tylko na ustalaniu przyczyn celowych? Piotr Sztompka pisze, że według antynaturalistów „nauka nie może ograniczać się do powierzchniowych fak- 
tów, obserwowalnych zmysłowo, lecz musi sięgać głębiej, do ukrytych właśnie, nieobserwowalnych znaczeń czy wartości wiązanych z faktami przez ludzi, a te ujawnić może dopiero rozumowa interpretacja" (Sztompka, 2002, s. 24). Nie wyklucza to jednak możliwości także rozumowego poszukiwania odpowiedzi na pytanie, co spowodowało dane działanie.

Nad metodą wyjaśniania rozumiejącego zawisło niebezpieczeństwo subiektywizmu, groźba niedotrzymania postulatu obiektywizmu, „czyli niezależności wiedzy od tego, kto ją formułuje" (tamże). Problem ten dostrzegał m.in. Karl Popper, podkreślając „rolę otwartej krytyki w środowisku naukowym jako mechanizmu kontroli i korekty jednostronnych poglądów”, a także Jürgen Habermas, optymistycznie zakładający warunki, których spełnienie może spowodować, że wyjaśnianie rozumiejące nabierze charakteru obiektywnego, a może się to dokonać, jeśli jest formułowane „,W drodze otwartej dyskusji z udziałem wielu badaczy w warunkach «idealnej sytuacji komunikacyjnej», czyli całkowitej swobody wypowiedzi, równej pozycji dyskutantów, braku jakichkolwiek nacisków zewnętrznych i argumentów niemerytorycznych" (tamże).

Spór między pozytywistycznymi zwolennikami wyjaśniania empirycznego zjawisk społecznych a humanistycznymi stronnikami wyjaśniania rozumiejącego, obecny w dyskursie metodologicznym od drugiej połowy XIX wieku, wnosił nowe spojrzenia na rolę jednego i drugiego podejścia badawczego. W rozwoju humanistycznego interpretacjonizmu zwraca uwagę wkład Maxa Webera, twórcy socjologii rozumiejącej, Eduarda Sprangera, twórcy psychologii rozumiejącej i Clifforda Geertza, twórcy antropologii rozumiejącej. Ewoluowały także poglądy pozytywistów, którzy w celu wyjaśniania ludzkich zachowań doskonalili umiejętności gromadzenia danych w badaniach empirycznych. Zaowocowało to na początku XX wieku pojawieniem się behawioryzmu w psychologii, a następnie $\mathrm{w}$ socjologii i politologii behawioryzmu wyrażającego pozytywizm w naukach społecznych.

Żadna $\mathrm{z}$ dwóch metod wyjaśniania zachowań ludzkich, a więc ani metoda wyjaśniania empirycznego, ani metoda wyjaśniania rozumiejącego, nie jest satysfakcjonująca, obie obarczone są niedoskonałościami, gdyż bazują na ograniczonej bazie danych. Pozytywistycznemu stanowisku zarzuca się powierzchowność, „skłonność do akcentowania tego, co łatwo mierzalne, a nie tego, co może być istotne z teoretycznego punktu widzenia”, a także „skłonność do skupiania się na zjawiskach, które łatwo zaobserwować" (Sanders, 2006, s. 50-51). Natomiast zalet podejścia behawioralnego upatruje się przede wszystkim $\mathrm{w}$ „determinacji jego zwolenników na rzecz podejmowania form analizy, które da się powtórzyć" (tamże, s. 53). Efektywność powtarzania badań i analiz zjawisk społecznych (politycznych) jest wszakże poważnie ograniczona, gdyż powtarzanie to dotyczy zjawisk wprawdzie tych samych, ale nie takich samych.

Z kolei wyjaśnianie rozumiejące jest bardziej lub mniej wypaczone, ponieważ badacz ma ograniczone możliwości wczucia się w role aktorów badanych 
wydarzeń, ograniczone możliwości zdiagnozowania sytuacji, w jakiej rozgrywały się wydarzenia, ograniczone możliwości odczytania intencji, motywów podmiotu działania społecznego itd. Te mankamenty w procedurze rozumienia rekompensuje nagromadzona od tysiącleci wiedza o zachowaniach ludzkich w danych warunkach, pozwalająca niekiedy wyjaśniać coś z dużym prawdopodobieństwem trafności: poniekąd przyczyny wielu działań społecznych są znane, dlatego można je interpretować humanistycznie poprzez porównanie, a także zrozumieć uprawdopodobniająco w świetle jakiejś teorii.

Należy też wspomnieć, że badaniami empirycznymi mogą być objęte tylko te działania społeczne, które są możliwe do zaobserwowania bezpośredniego, poprzez obserwację uczestniczącą bądź nieuczestniczącą w danym miejscu i czasie, przy czym każdy bezpośredni współobserwator może dostrzegać je oraz interpretować inaczej. Wieloma wyjaśnieniami interpretacyjnymi przyczyn działań mogą skutkować również dane pochodzące z badań ilościowych i statystycznych. Wszystko to jest uwarunkowane szeregiem okoliczności, do czego tutaj się nie odnoszę. Zatem wcale nie jest tak, że wyniki badań empirycznych, nawet jeśli są prawdziwe (niezależnie od tego, co prawda znaczy dla filozofów), gwarantują właściwą odpowiedź na pytanie: „dlaczego coś zaszło?”. Wyjaśnianie obrazu zachowań uzyskanego w badaniach empirycznych metodami jakościowymi także wymaga w mniejszym lub większym zakresie uzupełniania wyjaśnieniami humanistycznymi. Współcześnie za oczywiste należy przyjąć traktowanie ujęć pozytywistycznego i humanistycznego jako wzajemnie się uzupełniających (Kołodziejczak, 2009, s. 8; Karwat, 1998, s. 100). Wyjaśnienia empiryczne przyczyn działań społecznych tam, gdzie może to być pomocne w ich rozumieniu, powinny zawierać elementy interpretacji humanistycznej lub być w niej osadzone, a interpretację humanistyczną należy wspomagać danymi pochodzącymi z badań empirycznych.

$\mathrm{Na}$ potrzeby wyjaśniania komplementarnego, które nazwał integralnym, zwracał uwagę Jerzy Topolski, historyk i metodolog. Pod koniec lat 70. XX wieku kwestionował celowość rozróżniania wyjaśniania od rozumienia jako dwóch metod badań. Stwierdził, że nie uznaje „rozumienia za jakiś specjalny rodzaj procedury naukowej, różny od wyjaśniania (...), choćby nawet $\mathrm{z}$ wyjaśnianiem związanej jako (...) jego najgłębsza podstawa" (Topolski, 1978, s. 30). Prześledziwszy podstawowe poglądy na temat rozumienia, uznał, że „intuicyjne «wczuwanie się» czy ejdetyczne «zawieranie» własnego ja historyka dla "otwarcia się» na rozumienie innych są konstrukcjami wymykającymi się naukowej interpretacji” (tamże). Przede wszystkim jednak nie jest według niego słuszne wprowadzanie „do metodologii badań dwu niejako poziomów wyjaśniania: głębszego, gdzie można - drogą pozarozumową czy pozalogiczną, bo nie odwołującą się do wnioskowania - «dotrzeć» do motywów działań ludzkich przez (...) empatię, i drugiego, dotyczącego wyjaśniania w ściślejszym tego słowa znaczeniu" (tamże). 
Wyjaśnianie właściwe, nazywane przez Topolskiego „tylko wyjaśnianiem”, ściśle wiąże się - jego zdaniem - z pojęciem przyczyny, "jest więc ono zawsze wyjaśnianiem przyczynowym", procedurą spełniającą następujące aksjomaty (w historii): „1) wyjaśnianie w nauce historycznej jest rekonstrukcją związków przyczynowo-skutkowych (w szczególności zaś przyczyn) (...), 2) przyczyny są dwojakiego rodzaju: są to albo podejmowane w określonych warunkach decyzje ludzkie (których skutkiem są działania), albo fakty historyczne, czyli - inaczej mówiąc - rezultaty działań ludzkich, 3) przyczyna jest zawsze wcześniejsza od skutku i zakłada istnienie «wpływu» (oddziaływania) jednych elementów na inne (np. świata zewnętrznego na świat myśli i odwrotnie, faktów na fakty itd.)" (tamże, s. 31-32).

Topolski pyta: „Jaki wobec tego zakres pozostawiamy pojęciu rozumienia?”. Odpowiada, powtarzając myśl wyrażoną wcześniej, że jego zdaniem nie ma $\mathrm{w}$ nauce procedury rozumienia ,jako specjalnego typu postępowania badawczego, różnego od wyjaśniania działań ludzkich czy rezultatów tych działań" (tamże, s. 32). Istnieje natomiast „rozumienie historii (dziejów, nauki historycznej, świadomości historycznej społeczeństwa)”, i w tym sensie rozumienie „nie jest jakąś procedurą badawczą, lecz globalnym efektem różnych procedur (z wyjaśnianiem na czele)". Efekt ten nazywa Topolski efektem swoistym, gdyż nie chodzi tu „o rezultaty badań, lecz o nasze przekonanie, że tak jest rzeczywiście, jak to wyniki badania ujmują”. Przekonanie łączy się ze stopniowalnym pojęciem „oczywistości intelektualnej”. Znaczy to, że można być bardziej lub mniej przekonanym o prawdziwości sądów, a tym samym „uzyskać stan lepszego lub gorszego rozumienia”. Przekonanie jest czymś subiektywnym, dlatego „ten sam wynik badawczy może być dla jednej osoby przekonujący, a dla innej zaś nie". Celem postępowania badawczego - w którym wyjaśnianie stanowi najważniejszy, chociaż tylko jeden z wielu składników - jest rozumienie. Na uzyskanie stanu „rozumienia” wpływają wszystkie składniki badań, tworząc to, „co można by nazwać interpretacją" (tamże, s. 33).

Doprowadziło to Topolskiego do koncepcji wyjaśniania integralnego, której szczegółów nie ma potrzeby tu rozwijać (tamże, s. 188-205). Należy natomiast zwrócić uwagę na propozycję Tadeusza Klementewicza, który podjął się adaptacji wyjaśniania integralnego do rozumienia polityki. Teoretyk ten podkreślił, że pełne wyjaśnianie w humanistyce musi obejmować „zarówno struktury motywacyjne działań ludzkich, jak i wytwory działań". Jako adekwatną koncepcję interpretacji obu aspektów rzeczywistości uznał właśnie koncepcję wyjaśniania integralnego, ukierunkowującą syntezę „podejścia naturalistycznego i rozumiejącego" (Klementewicz, 2010, s. 110).

Klementewicz prezentuje "dyrektywę wyjaśniania integralnego w zastosowaniu do działań i procesów politycznych", przyjmując, że stosowanie się do niej służy pełnemu „wyjaśnieniu działań ludzkich oraz ich globalnych rezultatów". Wyjaśnianie integralne jest strukturą intencjonalnego wyjaśniania samych 
działań i przyczynowego wyjaśniania ich skutków. Intencjonalne wyjaśnianie działan dokonuje się „poprzez odtworzenie struktur motywacyjnych działań (celów, wiedzy o warunkach działań systemu wartości działających)", zaś przyczynowe wyjaśnianie skutków powinno być poprzedzone adekwatnym odtworzeniem „łańcucha faktów historycznych wiodących od konkretnych działań do interesujących badacza skutków”. Ten warunek dotyczy wyjaśniania zawierającego podsumowanie rezultatu „wielokierunkowych działań różnych podmiotów politycznych" (tamże).

Powyższy przegląd podstawowej wiedzy na temat trzech rodzajów wyjaśniania zjawisk społecznych wypada uzupełnić wzmianką o rodzajach wyjaśniania, które się z nimi krzyżują. Są one wyodrębnione według kryterium pytań, jakie zadaje badacz, chcąc wyjaśnić przyczynę czegoś. Do podstawowych rodzajów tego wyjaśniania należą: wyjaśnianie genetyczne, wyjaśnianie funkcjonalne, wyjaśnianie celowościowe, wyjaśnianie logiczne, a także ich różnorodne kombinacje, jak wyjaśnianie genetyczno-funkcjonalne, genetyczno-celowościowe, celowościowo-funkcjonalne.

W genetycznym wyjaśnianiu przyczyn danego stanu rzeczy stawia się pytania „dlaczego coś się stało?”, „co spowodowało coś?”. Określa się tu zaszłości, które przyniosły dany rezultat. Z kolei w wyjaśnianiu funkcjonalnym zasadniczym pytaniem jest: „jak jedno zjawisko warunkuje drugie zjawisko, jak na nie wpływa ze względu na funkcje jednego i drugiego w danej strukturze?". Aby określić funkcje, niezbędne jest umiejscowienie zjawisk w systemie, usytuowanie ich w danej strukturze, dlatego wyjaśnianie funkcjonalne powiązane jest z wyjaśnianiem systemowym (strukturalnym). W wyjaśnianiu celowościowym (teleologicznym) szuka się odpowiedzi na pytanie: „po co coś zaszło?”, szuka się celu danego rezultatu. Wyjaśnianie logiczne natomiast powinno opierać się na regułach odmian wnioskowania logicznego, czyli dedukcji, indukcji, redukcji, abdukcji i innych. Wszystkie te rodzaje wyjaśnień cechują zarówno wyjaśnianie pozytywistyczne, czyli tzw. naukowe, empiryczne, jak i wyjaśnianie humanistyczne (hermeneutyczne, interpretacjonistyczne, rozumiejące) oraz wyjaśnianie integralne.

\section{Działania polityczne i ich rezultaty jako przedmiot wyjaśniania}

Zjawiska wyjaśnia się, biorąc pod uwagę powiązania przyczynowo-skutkowe między nimi. Tworzą one proces przeplatających się przyczyn i skutków, w którym działania są przyczynami rezultatów, ale i one same mają swoje przyczyny, są rezultatem czegoś. Nowelizacja ustawy jest rezultatem działań legislacyjnych, ale działania legislacyjne są powodowane ustawą podlegającą nowelizacji. W łańcuchu przyczynowo-skutkowym działania są przyczynami danych stanów 
rzeczywistości, a dane stany rzeczywistości powodują podejmowanie działań. Zatem działania i ich rezultaty są zarazem tym, co wyjaśnia (eksplanans), i tym, co jest wyjaśniane (eksplanandum).

Politologia bada i wyjaśnia zarówno działania, jak i stany, które są ich efektem. Bada i wyjaśnia działania polityczne, których podmiotami są, jak zauważa T. Klementewicz, ci, którzy aktualnie kierują aparatem państwa, ci, którzy ubiegają się o kierowanie tym aparatem, i ci, którzy wpływają na treść decyzji podejmowanych przez rządzących (Klementewicz, 2013, s. 166). Analogicznie można pogrupować same działania na: kierowanie aparatem państwa, ubieganie się o kierowanie aparatem państwa i wpływanie na treść decyzji aparatu państwa. Natomiast rezultatami działań są, trzymając się „aspektów świata polityki” wymienionych przez Klementewicza, następujące stany rzeczywistości: 1) struktura organizacyjna aparatu państwa, system partyjny, normy prawne i kulturowe; 2) formy kultury ludzi uczestniczących w polityce, czyli ideologie, deklarowane opcje programowe partii, opinia publiczna, świadomość narodowa, historyczna, klasowa, stereotypy, mity rozpowszechnione w społeczeństwie; 3) wartości i normy życia politycznego; 4) środki i metody działań politycznych; 5) efektywność ekonomiczna i pozaekonomiczna działań politycznych; 6) stosunki międzynarodowe warunkujące życie polityczne (tamże, s. 167-169).

Zatem $\mathrm{z}$ jednej strony działania polityczne sprawiają, że aparat państwa ma taką lub inną strukturę, że istnieją zróżnicowane systemy partyjne, zróżnicowane regulacje prawne, formy uczestnictwa politycznego, ideologie itd. I tutaj uwidacznia się związek przyczynowy, w którym głosowanie w parlamencie jest przyczyną, a ustawa skutkiem. $Z$ drugiej strony zastana struktura aparatu państwa, regulacje prawne skłaniają ludzi do podejmowania działań mających na celu zmiany lub przeciwdziałanie zmianom. Innymi słowy, ustawa jest przyczyną, a głosowanie w sprawie jej nowelizacji - skutkiem.

Ale związki przyczynowo-skutkowe w polityce, tak jak w życiu w ogóle, nie ograniczają się do zależności między działaniami i ich przykładowymi rezultatami podyktowanymi modelem Klementewicza. Przyczynami działań politycznych są dyspozycje, czyli zinternalizowane, utrwalone w strukturach psychicznych ludzi skłonności lub nawyki, które powodują, że w danych okolicznościach postępują tak lub inaczej. Charakterystyczną cechą dyspozycji jest ich mniej lub bardziej podświadome przejawianie się. Jednostka kierująca się dyspozycją nie rozważa świadomie celów i uwarunkowań swego postępowania. Nieuświadomiony impuls podpowiada jej, jak ma postąpić w przypadku, gdy trzeba dokonać wyboru politycznego. Impuls może wychodzić z postawy danego człowieka, jego przekonań, kultywowanych przez daną jednostkę obyczajów, przestrzeganych przez nią wartości i wyznawanych ideologii, posiadanej opinii. U podstaw działań społecznych, w tym oczywiście i politycznych, leżą też intencje, cele, interesy, a więc to, co stanowi uświadomioną podstawę racjonalizacji działań (Jabłoński, 1991, s. 33-68). 
Na świecie podejmowane są nieustannie olbrzymie ilości działań politycznych wywołujących różnorodne skutki. Tylko niewielka ich część jest obserwowana bezpośrednio przez badaczy, tylko część przyciąga też uwagę naukowców. To badacze decydują o tym, co będą wyjaśniać, to oni selekcjonują obszary działań, które doprowadziły do wyjaśnianych przez nich stanów rzeczy, rekonstruują wydarzenia z bliższej i dalszej przeszłości, zbierają dane na temat tego, czym badane działanie było warunkowane. Stosują przy tym odpowiednie do tego metody i techniki badań, kierując się zastanymi uogólnieniami teoretycznymi i wskazówkami metodologicznymi. To różni wyjaśnianie naukowe (w tym wypadku zarówno empiryczne, jak i interpretacyjne) od wyjaśniania potocznego działań politycznych. To drugie, będące siłą rzeczy wyłącznie interpretacyjne, zachodzi w ograniczonym kontekście, oparte jest na fragmentarycznych informacjach, pozostaje uwikłane w spory polityczno-ideologiczne i moralne. Dotyczy to potocznego wyjaśniania działań znanych z dalszej przeszłości, jak i z wczoraj, z ostatnich dni. Badacz nie może przechodzić obojętnie obok interpretacji potocznych, których autorzy (politycy, dziennikarze i inni uczestnicy dyskursu politycznego) wyjaśniają działania minione i bieżące w celu kształtowania jakiejś sytuacji. Interpretując cudze interpretacje, w tym interpretacje podmiotu, którego działanie jest wyjaśniane (czyli uprawiając podwójną hermeneutykę), badacz znajduje się w kilwaterze dyskursu politycznego i albo podziela czyją́s potoczną interpretację i naukowo stara się ją uzasadnić, albo formułuje swoją, dysponując zgromadzonymi ku temu danymi i wiedzą. Może to zasadniczo czynić, jeśli uda mu się wyrwać $\mathrm{z}$ owego kilwateru lub jeśli nie da się w niego wciągnąć.

Sztuka wyjaśniania działań zależy od ich rodzajów, przy czym nie chodzi tu tylko o rodzaje wyszczególnione wyżej. Rozróżnia się działania jednostkowe, działania masowe, zachowania zbiorowe i działania zbiorowe. Działaniami masowymi są podobne działania podejmowane przez bardzo wielu ludzi. Działają oni pojedynczo, kierując się własnymi prywatnymi celami, indywidualnymi motywacjami, racjami i intencjami, jednakże może to powodować ważne konsekwencje dla całego społeczeństwa lub jego dużej części. Społeczne, gospodarcze i polityczne konsekwencje takich działań nie są ani zamierzone, ani przewidywane (Sztompka, 2002, s. 149-152). Z kolei przez zachowania zbiorowe rozumie się działania ludzi zgromadzonych w jednej przestrzeni, a także doświadczających tej samej sytuacji. Działania podejmowane są w pojedynkę, na własną rękę, obok siebie, a nie wspólnie (tamże, s. 152-155). Działania zbiorowe natomiast pojawiają się wtedy, kiedy „ludzie zdają sobie sprawę, że celów, jakie sobie postawili, nie da się zrealizować $\mathrm{w}$ pojedynkę, a jedynie razem $\mathrm{z}$ innymi, $\mathrm{z}$ udziałem innych, przy pomocy innych”. Ludzie działają tu nie tylko „obok siebie”, „równolegle" z aktywnością innych, ale także wspólnie: mają sformułowane cele, strategię postępowania, podział funkcji między uczestników i ich koordynację oraz wyłonione przywództwo (tamże, s. 155-157). Takie działania są wpisane w rolę 
społeczną różnych organizacji, są one również efektem dążeń jednostek, które swoją aktywnością skłaniają innych do wspólnego przedsięwzięcia.

Wyjaśnianie przyczyn działań politycznych i skutków, do których one doprowadziły, ma na celu tworzenie uogólnień teoretycznych służących następnie przewidywaniu zdarzeń ( $w$ drodze indukcji) albo kolejnemu wyjaśnianiu działań poprzez odnajdywanie ich odpowiedników w teorii (w drodze dedukcji). Wyjaśnianie służy też wyłącznie dowiedzeniu się, dlaczego coś zaszło. Odpowiedzi szuka się tu po to, aby to, co się stało, uczynić zrozumiałym, przekonującym, aby zaspokoić podstawową ciekawość świata polityki, aby dostarczyć sobie i innym bardziej pogłębionej wiedzy o polityce, nie ograniczając narracji do podstawowego odtwarzania faktów, aby uzasadnić system wartości czy utwierdzić kogoś w jego przekonaniach lub te przekonania podważyć. Wyjaśnia się również przyczyny zaistnienia jakiegoś stanu w celu kontynuowania działań, które przyniosły dobre efekty oraz przeciwdziałania tym, które uważa się za szkodliwe. Wreszcie przyczyny działań politycznych i ich skutków wyjaśnia się też po to, aby sprawdzić słuszność, poprawność, przydatność istniejącego uogólnienia teoretycznego, istniejących wyobrażeń. W praktyce podejmowanie działań w celu uzyskania spodziewanego rezultatu na podstawie błędnych założeń, mylącego wyobrażenia - może go nie przynieść albo doprowadzić do odwrotnego lub niepożądanego stanu.

\section{Praktyka wyjaśniania działań politycznych i ich rezultatów}

Metodami empirycznymi jest stosunkowo łatwo badać przyczyny działań masowych, zachowań zbiorowych i części działań zbiorowych tworzących politykę. Trudniej poddają się tym metodom przyczyny działań jednostkowych.

Przykład eksploracji przyczyn działań politycznych metodami behawiorystów stanowi badanie ankietowe wyborców polskich przed elekcją parlamentarną 13 października 2019 roku (Kulej, 2019). Przed wyborami (we wrześniu) zapytano ich, z jakiego powodu głosują na daną partię polityczną. Głosowano wprawdzie na komitety wyborcze, ale nie bądźmy zbytnimi formalistami. Badaniu poddano 1000 osób od 18. roku życia. Ankietowanym przedstawiono cztery odpowiedzi, z których mogli wybrać dwie. Były to: 1) „utożsamiam się z jej wartościami”, 2) „liczę na poprawę sytuacji mojej i mojej rodziny”, 3) „nie ma nikogo lepszego", 4) "nie chcę, żeby wygrała inna partia”. Odpowiedzi (dane w procentach) ułożyły się następująco. „Utożsamiam się z jej wartościami”: zwolennicy Prawa i Sprawiedliwości - 30, zwolennicy Koalicji Obywatelskiej - 31, zwolennicy Lewicy - 60. „Liczę na poprawę sytuacji mojej i mojej rodziny”: zwolennicy PiS - 38, zwolennicy KO - 14, zwolennicy Lewicy - 12. „Nie ma nikogo lepszego": zwolennicy PiS - 26, zwolennicy KO - 18, zwolennicy Lewicy - 18. 
„Nie chcę, żeby wygrała inna partia”: zwolennicy PiS - 9, zwolennicy KO - 41, zwolennicy Lewicy - 15.

Zatem tych, którzy odpowiedzieli (szczerze lub nieszczerze), że utożsamiają się z wartościami danej partii, wśród zwolenników Lewicy było dwukrotnie więcej niż wśród zwolenników PiS i KO. Z kolei tych, którzy liczyli na poprawę sytuacji swojej i swojej rodziny, wśród zwolenników PiS było ponad dwukrotnie więcej aniżeli wśród zwolenników KO i Lewicy. Blisko dwa razy więcej zwolenników PiS aniżeli zwolenników KO i Lewicy odpowiedziało, że głosowali tak z braku kogoś lepszego. Natomiast głosujących negatywnie, a więc tych, którzy nie chcieli, aby wygrała inna partia, po stronie zwolenników KO było najwięcej, bo trzykrotnie więcej niż po stronie zwolenników PiS oraz dwuipółkrotnie więcej niż po stronie zwolenników Lewicy. Wyniki te pokazują, że wśród zwolenników PiS dominowała chęć polepszenia sytuacji (w domyśle materialnej), wśród zwolenników KO - niechęć, by wygrała inna partia, a wśród zwolenników Lewicy - utożsamianie się z wartościami.

Wyniki tego badania, przy założeniu jego rzetelności i prawdziwości udzielanych odpowiedzi, ujawniły przyczyny, jakie mogły skłonić wyborców do oddania głosu na dane partie polityczne. Pokazały związek przyczynowo-skutkowy: głosuję na tę partię, gdyż odpowiadają mi jej wartości. W tym wypadku badany był motyw działania. Pytano, dlaczego ktoś postępuje tak, a nie inaczej. Skutkiem przyczyny, jaką stanowi podzielanie pewnych wartości, jest czyjś wybór kandydata na posła i postawienie krzyżyka przy jego nazwisku na karcie wyborczej.

Tutaj przyczyn głosowania na dane partie nie trzeba się domyślać, gdyż badanie przyniosło ich empiryczne wyjaśnienie. Przedstawione wyniki są uproszczone, ponieważ nie mówią, jakie dwie odpowiedzi wybrali ci sami respondenci. Pomińmy ten drobiazg i podkreślmy, że w badaniach na pytanie, dlaczego wyborcy opowiadali się za konkretnymi partiami, odpowiedź uzyskano bez potrzeby interpretowania preferencji wyborczych. Być może przed badaniami została sformułowana jakaś hipoteza, w której przypuszczono motywy wyborców, i ona się potwierdziła lub nie. Jednocześnie jest coś, co nie zostało wyjaśnione empirycznie, coś, co kwalifikuje się do wyjaśnienia interpretacyjnego. Można bowiem zapytać: dlaczego większość zwolenników PiS wiąże z tą partią perspektywy poprawy sytuacji swojej i swojej rodziny? Dlaczego większość popierających KO stanowią wątpliwi jej zwolennicy, skoro głosują, aby uszczuplić poparcie dla innej partii? Dlaczego zwolennicy Lewicy okazali się w świetle wyników badań ankietowych najbardziej ideowi? Zamiast „naukowo wyjaśniać”, można to próbować „humanistycznie zrozumieć”. Aby wyjaśnić empirycznie, należałoby szukać odpowiedzi, przeprowadzając kolejne badania ankietowe, wywiady, odwołując się do danych statystycznych. Można to wyjaśniać także interpretacyjnie na podstawie posiadanej wiedzy, śledzenia dyskursu w mass mediach, uprawdopodabniać przyczyny preferencji wyborców na podstawie danych pośrednich. Zgodnie 
z ideą wyjaśniania integralnego w miarę satysfakcjonujące wyjaśnienie powinno się uzyskać, łącząc wyjaśnianie empiryczne z interpretacją.

A oto inny przypadek badania przyczyn działania. Przemysław Żurawski vel Grajewski, wygłaszając we wrześniu 2019 roku wykład w Ognisku Polskim w Londynie na temat sytuacji geopolitycznej Polski, przedstawił interpretację incydentu dyplomatycznego między Izraelem a Polską, jaki wydarzył się w lutym 2019 roku po wypowiedzi p.o. izraelskiego ministra sprawa zagranicznych. Minister powiedział między innymi, że „Polacy wyssali antysemityzm z mlekiem matki”. Stało się to w momencie, kiedy finalizowano przygotowanie do spotkania przywódców państw Grupy Wyszehradzkiej w Jerozolimie. Wypowiedź ta spowodowała odwołanie spotkania w rezultacie wycofania się z niego rządu polskiego. Autor wykładu zauważył, że to, co się stało, „było sprzeczne z interesem państwa izraelskiego, a mimo to wydarzyło się i nie był to pierwszy incydent". Dodał, iż „Polska jest najbardziej przyjaznym krajem Unii Europejskiej wobec Izraela i burzenie tego stanu wydaje się absurdem", tym bardziej że politykom izraelskim trudno zarzucić emocjonalne prowokowanie takich incydentów. Prezentując swoje wyjaśnienie działania dyplomaty izraelskiego, powiedział, że stało się tak „ze względów, których możemy się jedynie domyślać”, że jego interpretacja nie jest poparta żadnym dowodem, że ,jest to czysta intuicja i pewna logika”. Scharakteryzował następnie sytuację na Bliskim Wschodzie, wskazując: 1) na wojskową obecność Rosji w Syrii u granic Izraela z możliwością oddziaływania na bezpieczeństwo $\mathrm{w}$ tym regionie; 2) na fakt zamieszkiwania w Izraelu około 1,7 miliona dawnych obywateli sowieckich ze swoimi sympatiami, mentalnością etc.; 3) na rosyjski sojusz z Iranem i prezydentem Syrii Baszarem Al-Asadem. Stwierdził, że jego zdaniem „daje to Rosji instrumenty do oddziaływania na bezpieczeństwo samego Izraela w skali, która pozwala Rosji składać różnorodne oferty temu państwu, takie, które są istotne $\mathrm{z}$ jego punktu widzenia. Jednym z głównych celów polityki rosyjskiej jest zniszczenie wyraźnie zaznaczającego się trendu wojskowej obecności amerykańskiej w Europie Środkowo-Wschodniej, z Polską w roli głównej jako kolejnym wiodącym sojusznikiem USA. Uderzenie w ten proces poprzez zniszczenie relacji polsko-izraelskich, polsko-żydowskich jest interesującym instrumentem wykonania tej operacji”.

Zatem to, co wyjaśnia działania izraelskiego p.o. ministra spraw zagranicznych, to celowa polityka rosyjska obliczona na wzniecenie wrogości w stosunkach polsko-izraelskich. Taka interpretacja wynika z przekonania, że Stany Zjednoczone traktują Izrael jako ważniejszego partnera aniżeli Polskę i w razie konfliktu między Polską a Izraelem będą sympatyzowały z Izraelem. To zaś może osłabić amerykańskie angażowanie się u zachodnich granic Rosji. Żurawski vel Grajewski zastrzegł mocno, powtarzając to dwa razy, że nie ma żadnego dowodu na swoje wyjaśnienie, że zostało ono „wydedukowane niczym u Sherlocka Holmesa". 
Czy powyższa interpretacja jest naukowa, czy jest to tylko potoczna spekulacja? Z pewną dozą umowności można przyjąć, że jest to wyjaśnienie o znamionach naukowych, gdyż wyrażony domysł nosi cechy hipotezy i został uprawdopodobniony scharakteryzowaną obiektywnie sytuacją, znajomością historii, interesów Rosji, wiedzą o możliwościach rosyjskiego wywiadu, rosyjskiej dyplomacji. Domysłu tego nie można na razie zweryfikować danymi empirycznymi. Nie można też wykluczyć, że dowody na rosyjski udział w próbie psucia stosunków polsko-izraelskich pojawią się kiedyś, choćby za pośrednictwem internetu, jak to się od pewnego czasu zdarza. Nie można oczywiście wykluczyć, że incydentu lutowego nie sprowokowały tajne służby Kremla, nie można wykluczyć, że był to irracjonalny wybryk polityka, w którym wzięły górę emocje wyrażające jego wartości. Wbrew opinii Żurawskiego vel Grajewskiego, że „rząd Izraela nie składa się z rozemocjonowanych pensjonarek, które w przypływie uczuć prowokują incydenty", historia dostarcza dowodów, że politycy to ludzie, którym pod wpływem emocji także zdarzają się nieprzemyślane i niefortunne zachowania.

Nasuwa się pytanie, jaki rodzaj wnioskowania znalazł zastosowanie w celu wyjaśnienia omówionego wyżej działania. Czy zostało ono wydedukowane, jak twierdzi jego autor? Gdyby była to dedukcja, tok rozumowania powinien być przykładowo następujący: „Wszystkie krzywdy na arenie międzynarodowej, które spotykają Polskę, są sprowokowane przez Rosję. Wypowiedź p.o. izraelskiego ministra była krzywdząca Polskę, a więc została sprowokowana przez Rosję". Ale Żurawski vel Grajewski nie zaryzykował takiego uogólnienia, zdając sobie sprawę - jak wolno sądzić - z jego fałszywości. Zasygnalizował natomiast konkurencyjną hipotezę. Jego wnioskowanie należy zatem zakwalifikować nie jako dedukcję, lecz inaczej.

Kierując się zachętą Karla Poppera do formułowania wielu śmiałych hipotez $\mathrm{w}$ procesie badawczym, można by wymyślić więcej motywów zachowania izraelskiego polityka, a potem z pasją je podważać i obalać, jak zalecał austriacki filozof. Tyle tylko, że w tym wypadku nie da się tego zrobić eksperymentami i obserwacją. Jeżeli nie uzyska się twardych, niezbitych dowodów obnażających przyczyny zaistniałego wydarzenia, to pozostają interpretacjonistyczne zabiegi, przy których pomocne może być wnioskowanie do najlepszego wyjaśnienia (po angielsku: inference to the best explanation), będące odmianą rozumowania abdukcyjnego bądź z nim utożsamiane (Grobler, 2006, s. 102). Wnioskowanie abdukcyjne nazywane jest też hipotetycznym. Znaczenie abdukcji rozwinął Charles Sanders Peirce, a ponieważ sposób jej pojmowania ewoluował u niego, „odpowiedzi na pytanie o naturę i strukturę rozumowań abdukcyjnych jest niemal tyle, ilu odpowiadających na nie" (Urbański, 2009, s. 37). Dość stwierdzić, że wyróżnia się trzy modele abdukcji: eksplanacyjno-dedukcyjny, eksplanacyjno-koherencyjny i apagogiczny (tamże, s. 41-102).

Tutaj ograniczamy się do zwrócenia uwagi, że od wnioskowania do najlepszego wyjaśnienia oczekuje się doprowadzenia „jedynie do ustalenia najlepsze- 
go, najbardziej adekwatnego, pasującego do faktów wyjaśnienia ze zbioru znanych, rywalizujących hipotez”, ewentualnie do sformułowania „nowej, lepiej tłumaczącej fakty hipotezy" lub pozyskania nowych danych empirycznych, które mogą sprawić, „że dotychczas przyjęte wyjaśnienie straci status «najlepszego»” (Sagan, 2014, s. 46). Termin „najlepsze wyjaśnienie” występuje w dwóch znaczeniach zaproponowanych przez Petera Liptona (Lipton, 2000, s. 5). W jednym z nich oznacza wyjaśnienie "najbardziej prawdopodobne” (likeliest), a w drugim - „najatrakcyjniejsze”, „najbardziej satysfakcjonujące” (loveliest). W pierwszym znaczeniu szuka się wyjaśnienia najlepiej uzasadnionego, a w drugim - najbardziej zrozumiałego. Te dwa znaczenia nie muszą się wykluczać. „Lipton twierdził, że wyjaśnienie najatrakcyjniejsze jest zarazem najbardziej prawdopodobne, ale niekoniecznie na odwrót, i dlatego najbardziej pożądane jest znalezienie wyjaśnienia o największej mocy eksplanacyjnej”, czyli najbardziej zrozumiałego (Sagan, 2014, s. 46).

\section{Zakończenie}

Wyjaśnianiu w naukach społecznych (w nauce o polityce) podlegają różnorodne zjawiska. Są to teksty, wydarzenia, działania, decyzje, akty prawne. Ich wyjaśnianie wymaga zróżnicowanych podejść, stosowania odmiennych procedur postulowanych w literaturze od dawien dawna. Część zjawisk łatwiej poddaje się interpretacjom, które prowadzą do ich uprawdopodabniania, część można w jakiejś mierze wyjaśniać empirycznie, odwołując się do zdobytych lub odkrytych dowodów, do danych uzyskanych w drodze obserwacji i doświadczeń. Wyjaśnianie interpretacyjne obciążone jest subiektywizmem badacza, jednostronnością lub ograniczonością poszukiwań danych wyjaśniających, a wyjaśnianie empiryczne - płynnością materii podlegającej wyjaśnianiu, niedoskonałością zmysłów badaczy i aparatu naukowego. Wyjaśniając zjawiska społeczne, szczególnie działania polityczne, trudno jest odkrywać prawidłowości, które można zawierać w uogólnieniach przyczynowo-skutkowych: nie ułatwia tego dynamika społeczeństwa, jego specyfika jako przedmiotu, a poza tym tylko część działań masowych i zbiorowych ma charakter względnie jednorodnych i cyklicznych. Jednostkowe działania polityczne - niezależnie od tego, czy jednorazowe, czy cykliczne - także podlegają zarówno wyjaśnieniom interpretacjonistycznym, jak i empirycznym. Można na przykład udowodnić, że poseł nie przyszedł na posiedzenie parlamentu, gdyż był chory. Z kolei przyczyna odwołania zaplanowanej wizyty prezydenta USA w Polsce w dniach 31 sierpnia-1 września 2019 roku może być tylko domniemana, a więc interpretowana. Ani prezydent nie jest w stanie udowodnić, że nie mógł przybyć do Polski z powodu zbliżającego się do wybrzeży USA huraganu, ani ktokolwiek inny nie udowodni jakiejkolwiek z hipotez, które się w tej sprawie pojawiły. Tam, gdzie się da, owocne może być już tylko lub głównie wy- 
jaśnianie empiryczne. Tam, gdzie nie da się czegoś wyjaśnić empirycznie, należy to interpretować. Biorąc zaś pod uwagę oczywistą niedoskonałość jednego i drugiego rodzaju wyjaśniania, powinno się w miarę możliwości oba integrować, stosować komplementarnie.

\section{Literatura}

Bachryj-Krzywaźnia, M. (2016). „Interpretacjonizm narratywistyczny. Filozoficzna geneza, założenia metodologiczne i potencjał analityczny". W: Ł. Dulęba, J. Wiśniewski (red.). Liberalizm i teoria polityczna. Poznań: Wydawnictwo Naukowe WNPiD UAM.

Bevir, M., Rhodes, R.A.W. (2006). „Teoria interpretacjonistyczna”. W: D. Marsh, G. Stoker (red.). Teorie i metody w naukach politycznych, przeł. J. Tegnerowicz. Kraków: Wydawnictwo Uniwersytetu Jagiellońskiego.

Giddens, A. (2001). Nowe zasady metody socjologicznej, przeł. G. Woroniecka. Kraków: Wydawnictwo Nomos.

Grobler, A. (2006). Metodologia nauk. Kraków: Wydawnictwo Aureus, Znak.

Jabłoński, A.W. (1991). Teorie politologiczne w nauce anglosaskiej. Wrocław: Wydawnictwo Uniwersytetu Wrocławskiego.

Karwat, M. (1998). „Specyfika metodologiczna i poziomy badań teoriopolitologicznych”. W: T. Łoś-Nowak (red.). Politologia w Polsce. Stan badań i perspektywy rozwojowe. Toruń-Wrocław: Wydawnictwo Adam Marszałek.

Klementewicz, T. (2010). Rozumienie polityki. Zarys metodologii o polityce. Warszawa: Dom Wydawniczy Elipsa.

Klementewicz, T. (2013). „Politologia jako wieloparadygmatyczna struktura wiedzy”. e-Politicon, 5, http://cejsh.icm.edu.pl/cejsh/element/bwmeta1.element.desklight-bfda487a-5147-4f62-8f7d-2d29a72b9fe2 (dostęp: 20.09.2019).

Kołodziejczak, M. (2009). „Hermeneutyka w nauce o polityce - formy obecności”. Przeglad Politologiczny, 3.

Krasnodębski, Z. (1986). Rozumienie ludzkiego zachowania. Rozważania o filozoficznych podstawach nauk humanistycznych i społecznych. Warszawa: PIW.

Kulej, M. (2019). „Na PiS głosują dla pieniędzy, a na KO - żeby PiS nie wygrało?”. Radio Zet Wiadomości, 24.09.2019, https://wiadomosci.radiozet.pl/Polska/Polityka/Wybory-parlamentarne-2019/Dlaczego-Polacy-glosuja-na-PiS-KO-i-Lewice-Sondaz-Kantar (dostęp: 10.10.2019).

Lipton, P. (2000). „Inference to the Best Explanation”. W: W.H. Newton-Smith (ed.). A Companion to the Philosophy of Science. Oxford: Blackwell, s. 184-193.

Marsh, D., Furlong, P. (2006). „Skóra, a nie sweter: ontologia i epistemologia w politologii”. W: D. Marsh, G. Stoker (red.). Teorie i metody w naukach politycznych, przeł. J. Tegnerowicz. Kraków: Wydawnictwo Uniwersytetu Jagiellońskiego.

Sady, W. (1996). „Cztery wielkie nurty metodologii nauki XX wieku”. Filozofia Nauki, IV, 2(14). 
Sagan, D. (2014). „Wnioskowanie do najlepszego wyjaśnienia jako metodologiczna podstawa teorii inteligentnego projektu”. Zagadnienia Naukoznawstwa, 1(199).

Sanders, D. (2006). „Behawioralizm”. W: D. Marsh, G. Stoker (red.). Teorie i metody w naukach politycznych, przeł. J. Tegnerowicz. Kraków: Wydawnictwo Uniwersytetu Jagiellońskiego.

Sztompka, P. (2002). Socjologia. Analiza społeczeństwa. Kraków: Znak.

Topolski, J. (1978). Rozumienie historii. Warszawa: PIW.

Urbański, M. (2009). Rozumowania abdukcyjne. Modele i procedury. Poznań: Wydawnictwo Naukowe UAM.

Żurawski vel Grajewski, P. (2019). Wykład o sytuacji geopolitycznej Polski. Relacja wideo z Londynu, wrzesień, https://www.facebook.com/JagiellonianUK/videos/399131497412171/UzpfSTE1MzI3Mzg5NDQ6MTAyMTM3OTQxNTY1OTg xMTE/?epa=SEARCH_BOX (dostęp: 15.10.2019)

\section{Streszczenie}

Artykuł porządkuje kwestie dotyczące wyjaśniania zjawisk społecznych, przede wszystkim działań politycznych. W literaturze wymienia się trzy rodzaje wyjaśnień: wyjaśnienie przyczynowe, wyjaśnienie interpretacyjne (humanistyczne, rozumiejące) oraz wyjaśnienie integralne, łączące te dwa. Autor omawia rodzaje wyjaśniania, przy czym termin „wyjaśnianie przyczynowe” zastępuje terminem „wyjaśnianie empiryczne”. Następnie charakteryzuje działania polityczne i ich rezultaty jako przedmiot wyjaśniania. W ostatniej części, na dwóch przykładach analizuje praktykę wyjaśniania empirycznego i interpretacyjnego. W odniesieniu do przykładu wyjaśniania interpretacyjnego przywołuje wnioskowanie abdukcyjne, czyli wnioskowanie do najlepszego wyjaśnienia. W procesie interpretacji, przy braku niezbitych dowodów, nie da się potwierdzić prawdziwości żadnej z hipotez. Można je tylko uprawdopodabniać lub uatrakcyjniać. Biorąc pod uwagę niedoskonałości wyjaśniania empirycznego i interpretacyjnego, należy dążyć do stosowania ich komplementarnie.

Słowa kluczowe: wyjaśnianie empiryczne, wyjaśnianie interpretacyjne, wyjaśnianie integralne, działania polityczne, naturalizm, antynaturalizm, wnioskowanie abdukcyjne 